\title{
The Speech Functions used by Ibu Muslimah and Pak Harfan in "Laskar Pelangi" Drama
}

Rahmania*

English Applied Linguistics Study Program, Post Graduate School, Medan State University, Indonesia

Corresponding Author: Rahmania, E-mail: rahmania.nyoe@gmail.com

\section{ARTICLE INFO}

Article history

Received: November 27, 2017

Accepted: December 25, 2017

Published: February 28, 2018

Volume: 9 Issue: 1

Advance access: January 2018

Conflicts of interest: None

Funding: None

\begin{abstract}
This research investigates kind of speech function used in utterances created by Ibu Muslimah and Pak Harfan in "Laskar Pelangi" drama. Descriptive qualitative method is conduct for this research. The script of drama Laskar Pelangi was taken as source of data. All utterances produced by bu Muslimah and Pak Harfan as the data in the research. In script of drama Laskar Pelangi it can find 18 statements, 10 questions, 3 commands and 11 offers. Each speech function produces by Ibu Mus and Pak Harfan with different total move. Ibu Muslimah makes 14 statements, 9 offers, 3 commands and 7 Question, while Pak Harfan makes 7 statements. 2 offer, 1 command and 3 questions. Ibu Mus is a dominant one she has more turn and interaction with student that pak Harfan. In addition based on speech function use by Ibu Muslimah it can see that the way of teacher in an area in Indonesia still used teacher centre in doing teaching.
\end{abstract}

Key words: Speech Functions, Qualitative

Method, Ibu Muslimah and Pak Harfan

\section{INTRODUCTION}

Language is tool for communication. Without language human live will be silent and have no interaction. Halliday in his book said that, Language is a pattern to give meaning. It determine by word, semantic system, and vocabulary of the language.

Social control is applied by language. It shares information, expression, feeling. It also can entertain the listener by show it in some media like film, novel, talk show and drama. Drama is kinds of literature that has written with dialogues that observe the elements which action and movement that performed on the stage. Sometimes, drama brings a variety of groups who want to learn a great experience. In Indonesia, drama is interested in the communities. Drama has a more dramatic atmosphere, besides that the language style of the actor/actress who became the main attraction.

Drama is an important role in influenced good or bad mindset towards people who come from different background. The actor and actress in drama will represent the language based on their character in drama.

Speech function analysis was a topic in this study. The analysis is conduct in a novel from a best seller book. There are speech function find in first page on scrict of "Laskar Pelangi":

Bu Mus : "Siapa Nama kau nak" (who is your name honey)

Lintang : : "Namaku Lintang dari kayu pelumpang bu, aku nak sekolah"

(My name is Lintang from Kayu Pelumpang Mam, I will Study)
$\mathrm{Bu}$ Mus

: "Subbahanallah, insyallah kau bisa sekolah nak, parkir sepeda kau disitu" (Subhanallah, InsyaAllah you will study honey, park your bicycle there)

Pak Harfan : "Siapa yang kau bawa itu Mus?" (Who is him?)

Bu MUs : "Lintang anak pesisir, insyaallah kita akan mendapatkan 10 murid hari ini" (Lintang a coastal child, InsyaAllah we will get ten students today)

In the dialogue above show different of speech function by different character. The researcher was interested analysis speech function used two main characters in the script.

\section{The Objective of Research}

The aim of this study is to find out the speech function used by Ibu Muslimah and Pak Harfan in "Laskar Pelangi” drama.

\section{Research Question}

The problem of the study is: What kinds of speech functions are used by Ibu Mus and Pak Harfan in "Laskar Pelangi" drama?

\section{LITERATURE REVIEW}

\section{The Definition of Drama}

The word of drama emanating from Greek language "Drau" which means is "Action" or does something. Aristoteles (in 
Endraswara, 2011:12) said that drama is "a representation of an action", similar with Aristoteles, Moulton (in Tarigan, 2000:70) said that drama presented in action. Performances have full code and symbols that keep a story from beginning until the end. Stories like this become an interesting drama. Drama which too easy to conjecture is precisely not interested. Drama is the literary form designed for the theater, where actors take the roles of the characters, performs the indicated action, and utter the writer dialogue (M.H. Abrams 1971: 43). Hellen in her book said that, drama is language combination from feeling, action in creative way.

Drama is kinds of literature that has written with dialogues that observe the elements which action and movement that performed on the stage.

\section{The Elements of Drama}

The six elements as they are involve: Plot, Theme, Characters, dialogue, Music, and Spectacle. In addition Lynch (2012) explains that elements of drama are: Plot, the design of the role play. Theme, the main topic implied of the story. Character, it is the personality of actor/actress in drama. Dialogue, the conversation used between the characteristic in drama. Music, the melody that will improve the harmony in role play. Spectacles, the attribute used in playing drama.

Drama of Laskar Pelangi is drama from a best seller novel by Andrea Hirata in 2005. The novel is narrated ten children from poor family in Belitung Island.

\section{Speech Function}

Norman Fairclough distribute speech function into four kind, statement, offer, command and question. One point to note immediately about the terms here is that only primary distinctions at a general level, 'Demand' for instance includes things which are not 'demands' in the ordinary sense of the term. So, while 'pint of Guineas please' might conceivably be said in a 'demanding' way - though 'please' makes that rather implausible - it is more likely to be called a 'request', or indeed an 'order' in the specific sense of 'ordering' food or drink in restaurants or pubs.

Halliday (1994: 69) explain the four primary speech functions, they are:

1. Command: linguistic expression for demand something to other.

Example: Borrow me your pen!

2. Offer: linguistic expression to give something to other. Example: Can I help you!

3. Statement: Linguistic expression to inform the hearer Example: I am a lecture

4. Question: Linguistic expression to asking the hearer Example: How old are you?

\section{Research Design}

Research design is the important thing in doing research. It is a planning to get a study. Nazir in his book said that. Research design is all the planning and process needed in doing a research. Descriptive qualitative method is conducted in doing this research. "Descriptive method is the method whose the purpose of which is to describe systematically, factually and accurately" (Isaac and Michael, 1987: 18). According to De Vos et al (2002:79) the qualitative method paradigm is in its broadest sense refers to research that elicits participant accounts of meaning, experience or perceptions. A qualitative study it concerned with non-static methods and small purposively selected samples. In this study, a descriptive method will be used to support by references of library research.

\section{Source and Sample of Data}

The script drama of Laskar Pelangi was taken as source of data. All utterance produced by bu Mus and Pak Harfan in the script that contain four primary of speech function taken as sample of the data.

\section{Data Collection}

Library research technique applies to take data. Next, the procedure are downloading the script Laskar Pelangi from Google on October 10 ${ }^{\text {th }}, 2016$ and then save on file in computer as the samples, after that analyzing the dialogue in script.

\section{Technique of Analyzing Data}

The theory of speech function by Norman Fairclough is used for analyzing data. The analyzing data in dialogue of Laskar Pelangi by the following techniques:

1. Reading all script of Laskar Pelangi,

2. Choosing the speech function

3. Putting the kinds of speech function into a list,

4. Explaining the findings based on the research question.

\section{RESULT}

After collecting the data, the dialogue is classified based on the kinds of speech function. The summarized of four kinds of speech function found in script as follow:

There are four types of speech function classified by Norma Fairclough, statement, command, offer and question. Table 1 shows that the four basic type of speech function are found in the script.

Ibu Muslimah and pak Harfan produce 45 number of speech which divided into 18 statements, 11 offers, 4 command and 10 questions.

\section{The Discussions and Findings}

The Analysis of Speech Function in "Laskar Pelangi” Script Drama

\section{Statement}

The speech function of statement has aim to give information, share some idea, or to sure and receive the information.

From the transcript drama of Laskar Pelangi, there are the dialogues from some character. In this research, researcher 
analyzes the dialogue of Ibu Muslimah and pak Harfan. 18 statements are found in the script.

The speech function "statement" which produce by ibu Muslimah is follow:

Excerpt 1 show that Ibu Muslimah states the statement to her student to give some information, in the other utterance $\mathrm{Bu}$ Mus receive the information by saying "Bagus sekali anak pesisir, betul-betul sekali" ("Very good coastal child, it is correct.")

Excerpt 2 Show the Statement above which is state by Ibu Muslimah is to give information to her head master.

Excerpt 3 shows the Three utterances above express the speaker's ideas, based on Pak Harfan's statement on script.

Excerpt 4 shows the utterance "Iyela" express the speaker receive the information that give by pak Harfan.

The utterances above show that speech function in this excerpt is "statement" which is used by Ibu Muslimah is giving information to her leader (Pak Harfan) as headmaster at school. On the other hand, Bu Mus receive the information by saying the utterance like "Iyela"
The Speech Function "statement" state by pak Harfan is follow:

Excerpt 5 shows the Statements above which is stated by pak Harfan is giving information to Ibu Muslimah.

Excerpt 6 shows the Two long utterances above clarify as the statements because of the utterances are the information that gives by Pak Harfan to the students.

Ibu Mus is the dominant speaker who plays the role as the teacher by giving some information to her students and leader about the school. While pak Harfan is the character who produce the a bit than Ibu Muslimah. It because he is a leader that not has many turn to speak more with students.

\section{Question}

Question is linguistic expression to asking information. In script drama of Laskar Pelangi researcher analysis the question is stated by Ibu Muslimah and Harfan.

11 questions found in transcript drama of Laskar Pelangi who produce by Ibu Muslimah dan Pak Harfan. The

Table 1. The Total of Speech Function used by Ibu Muslimah and Pak Harfan in Dialogue "Laskar Pelangi" Drama

\begin{tabular}{llcccc}
\hline NO & Speaker & Statement & Offer & Command & Question \\
\hline 1 & Ibu Muslimah & 11 & 9 & 3 & 7 \\
2 & Pak Harfan & 7 & 2 & 1 & 3 \\
& Total & 18 & 11 & 4 & 10 \\
\hline
\end{tabular}

Excerpt 1.

\begin{tabular}{|c|c|c|c|c|}
\hline $\begin{array}{l}\text { Speech } \\
\text { Function }\end{array}$ & Turn/moves & Speaker & Utterances & The translation \\
\hline Statement & 11 & Ibu Mus & $\begin{array}{l}\text { "Subhanallah, insyallah kau bisa } \\
\text { sekolah nak" } \\
\text { "Kucai menjadi ketua kelas adalah } \\
\text { sosok yang mulia, bukankah di } \\
\text { alqur'an sudah diterangkan, nanti } \\
\text { dirimu juga akan mendapatkan } \\
\text { balasan yang setimpal akan hal } \\
\text { tersebut" } \\
\text { "Bagus sekali anak pesisir, betul-betul } \\
\text { sekali ." } \\
\text { "Bentar lagi sayang } \\
\text { Tapi ingat, kita tak punya dana untuk } \\
\text { semua itu" } \\
\text { Nilai kalian ni jelek-jelek semua, } \\
\text { menurun semua, terutama kau lah } \\
\text { Mahar dan Flo. Kau Mahar, semenjak } \\
\text { kehadiran Flo nilai mu menurun, }\end{array}$ & $\begin{array}{l}\text { "Subhanallah, Insyaallah You can study } \\
\text { honey" } \\
\text { "Kucai be a leader in the class is a noble } \\
\text { figure, is it not, that in Quran it have told, you } \\
\text { will get a decent reply for that thing" } \\
\text { "Very good coastal child, it is correct." } \\
\text { "It will be come soon honey, but remember, } \\
\text { we haven't fund for all" } \\
\text { "Your score weren't good, it come down, } \\
\text { especially you Mahar, When Flo came your } \\
\text { score is sagging. }\end{array}$ \\
\hline
\end{tabular}

Excerpt 2.

\begin{tabular}{lclll}
\hline Speech Function & Turn/moves & Speaker & Utterances & The translation \\
\hline Statement & 11 & Ibu Mus & "Lintang anak pesisir, Insyaallah kita & "Lintang is coastal child, \\
& & & akan mendapatkan 10 murid hari ini"” & $\begin{array}{l}\text { InsyaAllah we will ge ten } \\
\text { students today" }\end{array}$ \\
\hline
\end{tabular}


Excerpt 3.

\begin{tabular}{|c|c|c|c|c|}
\hline Speech Function & Turn/moves & Speaker & Utterances & The translation \\
\hline Statement & 11 & Ibu Mus & $\begin{array}{l}\text { Lalu saye nak tinggalkan pak cik } \\
\text { beruda saja dengan Bakrie, } \\
\text { mimpi aku tu menjadi guru bukan } \\
\text { jadi istri saudagar, soal uang } \\
\text { aku sudah mendapatkannya } \\
\text { dari menjahit. } \\
\text { Aku lupa memisahkan kertas } \\
\text { ulangan harun" } \\
\text { Tapi aku tak suka cara mereka, } \\
\text { begitu meremehkan Harun" }\end{array}$ & $\begin{array}{l}\text { "While I will leave you here with } \\
\text { Bakrie, My dream is to be a teacher, it } \\
\text { is not to be a wife of rich man, about } \\
\text { money I get it from sewing. } \\
\text { I forget to separating Harus's paper" } \\
\text { But, I don't like the way they so } \\
\text { disparaging Harun" }\end{array}$ \\
\hline
\end{tabular}

Excerpt 4.

\begin{tabular}{lclll}
\hline Speech Function & Turn/moves & Speaker & Utterances & The translation \\
\hline Statement & 11 & Ibu Mus & Iyela & Oh Yes \\
\hline
\end{tabular}

Excerpt 5.

\begin{tabular}{|c|c|c|c|c|}
\hline Speech Function & Turn/moves & Speaker & Utterances & The translation \\
\hline Statement & 11 & Pak Harfan & $\begin{array}{l}\text { Mus ini sudah lewat pukul } 11.00 \text { kita } \\
\text { harus memberitahu para orang tua } \\
\text { mereka itu, bahwa kita harus... } \\
\text { Tapi kau juga harus tau, apalah arti } \\
\text { surat ini"” } \\
\text { Sudahlah, Bakrie bisa membantuku } \\
\text { untuk membersihkan ini semua } \\
\text { Ndak ada yang bisa kita lakukan } \\
\text { lagi mus, surat dari pengawas } \\
\text { sekolah sumatera selatan ini jelas } \\
\text { mengatakan untuk ulangan umum } \\
\text { minggu depankita harus bergabung } \\
\text { dengan SD PN TIMAH } \\
\text { Tak apa mus" Ku serahkan semuanya } \\
\text { padamu Mus, aku rasa anak - anak } \\
\text { akan bahagia saat mendengarnya" }\end{array}$ & $\begin{array}{l}\text { Mus, It was eleven more, we } \\
\text { need to said to all the parents, } \\
\text { that we must. } \\
\text { But, you must also know what } \\
\text { the meaning of this letter } \\
\text { It is okey, Bakrie can help me to } \\
\text { clean it all. } \\
\text { There is nothing we can do } \\
\text { more, the letter from supervisor } \\
\text { of south Sumatera School tell } \\
\text { clearly for this examination, } \\
\text { next week we must join } \\
\text { with Primary school of PN } \\
\text { Timah (SD PN TIMAH) } \\
\text { It is okey Mus, I gave all to } \\
\text { you. I think the students will } \\
\text { happy when know this. }\end{array}$ \\
\hline
\end{tabular}

Excerpt 6.

\begin{tabular}{|c|c|c|c|c|}
\hline Speech Function & Turn/moves & Speaker & Utterances & The translation \\
\hline Statement & 11 & Ibu Mus & $\begin{array}{l}\text { "Mereka yang ingkar telah diingatkan } \\
\text { bahwa air bah akan datang. Namun } \\
\text { kesombongan telah membutakan mata } \\
\text { dan menulikan telinga mereka, dan } \\
\text { akhirnya mereka musnah dilamun } \\
\text { ombak" } \\
\text { "313 tentara islam itu mengalahkan } \\
\text { ribuan tentara Quraisy bersenjata } \\
\text { lengkap, anak anakku kekuatan itu } \\
\text { dibentuk oleh iman, bukan oleh jumlah } \\
\text { tentara, jadi ingatlah anak-anakku, } \\
\text { teguhkan pendirianmu, kalian harus } \\
\text { punya ketekunan, harus punya keinginan } \\
\text { yang kuat, untuk mencapai cita-cita, } \\
\text { sekian dari bapak kalian boleh istirahat" }\end{array}$ & $\begin{array}{l}\text { "The people who disclaim were } \\
\text { reminded flood will come. } \\
\text { Nevertheless their vanity have } \\
\text { blind their eyes and deafen their } \\
\text { ears, and in the last they destroyed } \\
\text { by waves." } \\
\text { "313 the army of Islam beat } \\
\text { thousand of Quraisy army with } \\
\text { panoplies. The students. the strong } \\
\text { is made by faith. It is not by the } \\
\text { total of army. So, remember that } \\
\text { my children, confirm your position, } \\
\text { you must have diligence, a strong } \\
\text { desire, to get the goal, It is all from } \\
\text { me you can take a rest. }\end{array}$ \\
\hline
\end{tabular}


Questions state by Ibu Muslimah and Pak Harfan is to their student. In this case Ibu Muslimah has more questions than Pak Harfan.

\section{CONCLUSION}

There are four kinds of speech function produce by Ibu Muslimah and Pak Harfan in Drama Laskar Pelangi. In script of drama Laskar Pelangi it can find 18 statements, 10 questions, 3 commands and 11 offers. Each speech function produces by Ibu Mus and Pak harfan with different total move. Ibu Mus is a dominant one she has more turn and interaction with student that pak Harfan. In addition based on speech function use by Ibu Muslimah it can see that the way of teacher in an area in Indonesia still used teacher centre in doing teaching.

For the reader and the other researcher, it is suggested to get more understanding about speech functions. It is important to get a lot theory and analyzing completely in doing research.

\section{REFERENCES}

Abram, M. H. (1971). A Glosary of Literary Terms (3rded). New York: Holt, Rinehart and Winston, Inc.

Burns, R. (1999). Introductions of Research Methods. Melbourne: Longman House

Catur Wahono, M. (2014). The Speech Functions Analysis in Utterances Used by Alex Hitches and Sara Mendes In
"Hitch" Movie. Faculty of Humanities Dian Nuswantoro. University of Semarang.

Endraswara, Suwardi. (2011). Metodologi Penelitian Sastra. Jakarta. PT.Buku Seru

Eggins, S. (1994). An Introduction to Systemic Functional Linguistics. London: Convent Garden.

Halliday, M.A.K, Hasan,R. (1985). Language, Context, and Text. Oxford: Oxford University Press.

Halliday, M.A.K. (1994). An Introduction to Functional Grammar. $2^{\text {nd }}$ edn. London: Edward Arnold. https://en.wikipedia.org/wiki/Laskar_Pelangi

Isaac, S., \& Michael, W. B. (1987). Handbook in Research and Evaluation. San Diego, CA: Edits Publishers.

Martin, J.R. (1992). English Text System and Structure. Amsterdam: University of Sydney.

Nazir, M. (1988). Metode Penelitian. Jakarta: Ghalia Indonesia.

Nicholson H. (2000). Teaching Drama 11-18 ed. London: Continum.

Norman, F. (2004). Analysing Discourse Textual Analysis for Social Research. London. The Taylor \& Francis e-Library.

Ridha R. (2013). Speech Function and Speech Role in Carl Fredricksen's Dialogue on "Up" Movie. English Department, Faculty of Languages and Arts State University of Medan (UNIMED)

Schiffrin, D. (1994). Approaches to Discourse. Oxford: Blackwell.

Tarigan, D. (2000). Pendidikaan Keterampilan Berbahasa. Jakarta. Universitar Terbuka 